\title{
Ultralyd i norsk ambulansetjeneste
}

\section{Av Lars Petter Bjørnsen}

Point-of-care ultrasonography (POCUS) er veletablert i den akuttmedisinske kjeden ved bruk i luftambulansetjenesten, på legevakt og i akuttmottakene. Nå bør man også innføre en mer organisert bruk av ultralyd i ambulansetjenesten i Norge.

\section{Bakgrunn}

I enkelte land er allerede POCUS etablert eller på vei inn ambulansetjenesten [1]. Sykepleiere ved Skaraborg sykehus i Sverige gjennomgikk for eksempel et pilotprosjekt kalt PAULUS (Prehospital Ambulanssjuksköterske-ledd UltraLjudsUnderSökning). Ultralyd er dog allerede innlemmet i læringsplanen på universitetsnivået for enkelte sykepleie- og paramedisinerutdanninger i Norge, men dette er ikke løftet til et nasjonalt nivå. Masterstudenter i Prehospital Critical Care ved Universitetet i Stavanger (UiS) har allerede startet med en formell ultralydutdanning gjennom et prosjekt ledet av førsteamanuensis Nils Petter Oveland. Nå er det her også startet undervisning i ultralyd ved enkelte spesialsykepleieutdanninger og paramedisinerutdanningen (Paramedic-utdanningen). Ultralydbruk anvendes bredt i utdanningen og brukes både som et verktøy i anatomi- og fysiologiundervisningen, samt i den kliniske vurderingen av pasienter. I de ulike helseforetakene er ultralyd brukt i varierende grad i ambulansetjenesten. Sykehuset Innlandet har i henhold til sin kompetanseplan iverksatt bruk av ultralyd, mens Universitetssykehuset i Nord-Norge har gjennomført et prosjekt med ultralydveiledet perifer venetilgang. Sørlandet sykehus har gjennomført prosjektet «Infarktambulansen» ledet av Lars Jacobsen i regi av SNLA, hvor ambulansepersonell ble trent opp til å ta hjertebilder i felt som deretter ble tolket av kardiolog. Helse Midt-Norge

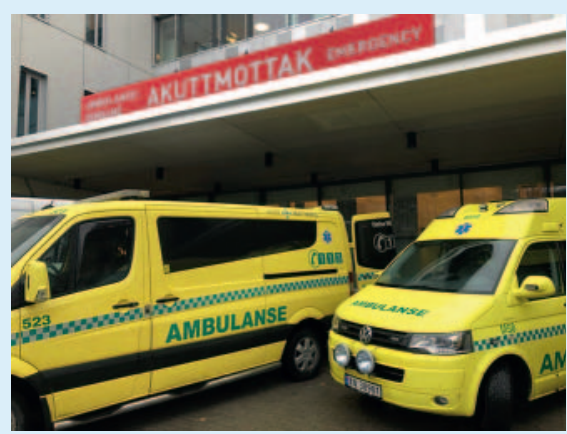

ønsker også å se på muligheten av å implementere POCUS i ambulansetjenesten (POCUS HMN). Det mangler en enhetlig tilnærming til hvilken rolle POCUS skal ha i utdanningen av ambulansepersonell og $\mathrm{i}$ ambulansetjenesten.

\section{Hvorfor ultralyd i ambulansetjenesten?}

Målet med innføring av ultralyd i ambulansetjenesten er økt pasientsikkerhet gjennom bedret prehospital diagnostikk og behandling, valg av adekvat leveringssted for pasienten og tidligere informasjonsformidling til akuttmottakene. Fokuset er ment å være på algoritmer og protokoller, samt at ultralydundersøkelsen skal kunne svare på et konkret klinisk spørsmål. Disse kliniske spørsmålene vil kunne besvares med ja eller nei, - for eksempel finnes det lungeglidning eller er det fri væske i buken? Ultralydbruk i ambulansetjenesten skal utgjøre enkle og begrensede protokoller som utføres direkte på pasientene i den prehospitale settingen.

\section{Klinisk effekt}

Studier har vist at bruk av POCUS gir nødvendig tilleggsinformasjon i over $15 \%$ av oppdragene [2] og at bruken understøtter den kliniske mistanken ved for eksepmpel dehydrering, pneumotoraks, lun- geødem, pleuravæske, hjertesvikt og fri væske i buken etter traume. Samtidig letter det igangsetting av nødvendig behandling ved å fasilitere etablering av venetilgang. En annen studie viste endret behandling i $21 \%$ av tilfellene [3] hvor ultralydbruk ofte fikk konsekvenser for volumbehandling, samt også valg av transportmåte eller leveringssted. Utvikling av en kompetanseplan må bygge på studier og være tilrettelagt for ambulansetjenesten. Det må foreligge klare retningslinjer for bruk og diskusjon rundt nytten og begrensningene av POCUS må vektlegges.

\section{Utdanningsprogram}

Det finnes ingen standardisert opplæringsprogram for POCUS innrettet på ambulansetjenesten. Studier viser at det er stor variasjon i faglig omfang og tidsbruk for opplæringen. En systematisk oversikt fra 2017 fant at opplæringen av ultralydnaive paramedisinere varierte fra 2 minutter til et par dager, inkludert didaktisk og praktisk trening. Mens opplæringen av norske, uerfarne sykepleiere i akuttmottak i ultralydveiledet femoralisblokkade, ble gjennomført som et dagskurs [4]. De fleste studier fokuserte hovedsakelig på traumeundersøkelse (FAST) [5]. Det vil være nyttig å etablere en felles nasjonal kompetanseplan hvor man legger opp til et helhetlig utdanningsløp gjennom universitetsutdanningen og videreutdanning som ferdig utdannet ambulansepersonell.

\section{Bruksområder}

\section{Kliniske undersøkelse}

Ambulansepersonellet står overfor kliniske problemstillinger hvor avklaring med ultralyd vil rettlede den første behandlingen. I motsetning til auskultasjon kan UL-under- 
søkelse gjennomføres uten større vansker selv ved høyt støynivå og i bevegelse for eksempel under transport [6]. Det kan være å skille mellom ulike årsaker til respirasjonsbesvær ved å avdekke for eksempel lungeødem, pleuravæske eller pneumothoraks, eller avdekke blødning ved hypotensjon eller traume. Tidlig oppdagelse av potensielt livstruende skader, f.eks intraperitoneal blødning, kan styrke mulighetene for godt forberedt pasientmottak i sykehus.

\section{Respons på behandling}

Bruk av ultralyd i ambulansetjenesten vil også kunne rettlede og vurdere effekten av behandlingen som blir gitt. Ultralyd er nyttig i for eksempel vurdering av væskestatus, samt hjertekontraktilitet under resuscitering.

\section{Smertelindring}

Et annet spennende bruksområde som kan være aktuelt for ambulansetjenesten er ultralydveiledede nerveblokkader. Bruk av slike blokkader vil kunne redusere bruken av systemiske analgetika. Studier har vist at en sykepleier med tilstrekkelig opplæring kan levere slik behandling på samme nivå som en lege [7]. Det er grunn til å tro at disse studiene kan overføres til ambulansepersonell.

\section{Telemedisin}

I tillegg til at Ambulansepersonell tolker ultralydfunn på egen hånd kan de også sende relevante ultralydbilder for vurdering av spesialister i spesialisthelsetjenesten. Dette kan omfatte flere fagområder som kirurgi, obstetrikk og lunge, og er allerede utprøvd innen fagområde kardiologi i Kristiansand.

Foreslåtte protokoller eller anvendelsesområder:

- eFAST - Traumeundersøkelse

- Føtal hjertefrekvens

- Frakturer i rørknokler

- RUSH protokoll

- Ultralydveiledede prosedyrer (f.eks nerveblokkade, perifer venekanylering)

\section{Konklusjon}

Bruk av ultralyd er på vei inn i ambulanseutdanningen og -tjenesten, men det mangler en god helhetlig kompetanse- og utdanningsplan i Norge. Det er flere pågående prosjekter med POCUS ved enkelte utdanningsinstitusjoner og ambulansestasjoner, men det mangler en enhetlig og omforent tilnærming til kompetanse- og utdanningsplan. I denne utviklingsfasen vil det være nyttig å trekke til seg fagressurser fra hele den akuttmedisinske kjeden og bruke erfaringer fra andre deler av landet. Opprettelse av et nasjonalt nettverk vil være en vei å gå og en fornuftig strategi er å komme fram til et omforent curriculum og krav til utdanningsakti- viteter som tar for seg hele utdanningsforløpet fra universitetsnivå til helseforetak.

\section{References}

[1] Nelson BP, Chason K. Use of ultrasound by emergency medical services: a review. Int J Emerg Med 2008; 1: 253-259. doi:10.1007| s12245-008-0075-6

[2] Hoyer HX, Vogl S, Schiemann U et al. Prehospital ultrasound in emergency medicine: incidence, feasibility, indications and diagnoses. Eur J Emerg Med 2010; 17: 254-259. doi:10.1097| MEJ.0b013e328336ae9e

[3] Walcher F, Weinlich M, Conrad G et al. Prehospital ultrasound imaging improves management of abdominal trauma. The British journal of surgery 2006; 93: 238-242. doi:10.1002/bjs.5213

[4] Saga E. Nurse led ultrasound guided femoral nerve block in hip fracture patients - a study of task shifting. Ultraschall in Med - European Journal of Ultrasound 2021; 42: 439

[5] Meadley B, Olaussen A, Delorenzo A et al. Educational standards for training paramedics in ultrasound: a scoping review. BMC Emerg Med 2017; 17: 18 doi:10.1186/s12873-017-0131-8

[6] Snaith B, Hardy M, Walker A. Emergency ultrasound in the prehospital setting: the impact of environment on examination outcomes. Emerg Med J 2011; 28: 1063-1065. doi:10.1136/ emj.2010.096966

[7] Laurant $\mathrm{M}$, van der Biezen $\mathrm{M}$, Wijers $\mathrm{N}$ et al. Nurses as substitutes for doctors in primary care. Cochrane Database Syst Rev 2018; 7: CD001271 doi:10.1002/14651858.CD001271. pub3 